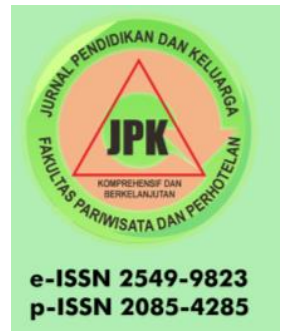

JURNAL PENDIDIKAN DAN KELUARGA

Vol. 11 No.02, 2019 Page 38-47

DOI: https://doi.org/10.24036/jpk/vol11-iss02

available at http://jpk.ppj.unp.ac.id/index.php/jpk/index

\title{
PENGARUH BAURAN PROMOSI TERHADAP KEPUTUSAN PEMBELIAN KAMAR DI HOTEL DAIMA PADANG
}

\author{
Afri Yandi Zaputra ${ }^{1}$, Yuliana ${ }^{2}$ \\ 1,2 Program Studi D4 Manajemen Perhotelan, Jurusan Pariwisata, Fakultas Pariwisata \\ dan Perhotelan,Universitas Negeri Padang. \\ 2 Fakultas Pariwisata dan Perhotelan, Universitas Negeri Padang. \\ Email: yuliana@fpp.unp.ac.id
}

\begin{abstract}
The purpose of research is to determine the effects of Promotion mix to Room Purchasing Decision in Hotel Daima Padang. This type of research is quantitative with associative causal methods. The population in this study is the guests who have stayed with the monthly average is 1.555 people. Sampling technique is non probability sampling, using purposive sampling method. Number of sample in this research amounted to 94 people. Data collection using a questionnaire based with Likert Scale that tasted for validity and reliability. The results showed that: (1) Promotion mix is in the good category with a parcentage of $57 \%$, (2) Puchasing decisions are in the good category with a percentage of $71 \%$, (3) The results of the study using the $t$ test showed that the five indicators of the promotion mix (Advertising, Personal selling, Sales promotion, Public relation and Direct marketing) room purchasing dicisions as the dependent variable significantly with the value of $R$ square of 0,239 .
\end{abstract}

Keywords: promotion mix, puchasing decision

\begin{abstract}
Abstrak
Penelitian ini bertujuan untuk mengetahui Pengaruh Bauran Promosi Terhadap Keputusan Pembelian Kamar di Hotel Daima Padang. Jenis penelitian ini adalah kuantitatif dengan metode asosiatif kausal. Populasi dalam penelitian ini adalah tamu yang menginap dengan rata-rata perbulan yaitu 1.555 orang. Teknik pengambilan sampel adalah non probability sampling, dengan menggunakan metode purpossive sampling. Jumlah sampel dalam penelitian ini berjumlah 94 orang. Pengumpulan data menggunakan angket berdasarkan Skala Likert yang telah teruji validitas dan reliabilitasnya. Hasil penelitian menunjukan bahwa: (1) Bauran Promosi berada pada kategori baik dengan persentase 57\%, (2) Keputusan Pembelian berada pada kategori baik dengan persentase 71\%, (3) Hasil penelitian dengan menggunakan uji t menunjukan bahwa kelima indikator bauran promosi (periklanan, penjulan tatap muka, promosi
\end{abstract}

This is an open access article distributed under the Creative Commons 4.0 Attribution License, which permits unrestricted use, distribution, and reproduction in any medium, provided the original work is properly cited. (C2017 by author and Universitas Negeri Padang. 
penjualan, hubungan masyarakat dan pemasaran langsung) mempengaruhi keputusan pembelian sebagai variabel dependen secara signifikan dengan nilai $\mathrm{R}$ square sebesar 0,239 .

Kata Kunci: Bauran Promosi, Keputusan Pembelian

\section{Pendahuluan}

Sumatera Barat sebagai daerah tujuan wisata di Indonesia ternyata semakin di kenal oleh wisatawan mancanegara. Salah satu kota atau kabupaten yang memiliki potensi sebagai objek wisata adalah kota padang. Kota Padang memiliki beberapa tempat tujuan wisata seperti wisata alam, wisata kuliner, wisata sejarah dan wisata belanja. Hal ini merupakan suatu daya tarik para wisatawan untuk melakukan kunjungan ke Kota Padang. Selanjutnya kondisi tersebut memicu perkembangan industri jasa perdagangan, jasa pariwisata dan jasa perhotelan di Kota Padang.Maraknya wisatawan yang berkunjung ke Kota Padang menyebabkan Kota Padang menjadi salah satu tempat berkembangnya industri perhotelan, terlihat dari banyaknya hotel-hotel yang baru bermunculan.

Manurut Budi (2013: 2), "Hotel adalah salah satu usaha yang bergerak dalam bidang jasa untuk mencari keuntungan melalui suatu pelayanan kepada para tamunya yang menginap seperti pelayanan kantor depan, tata graha, makan dan minum, MICE, serta rekreasi". Untuk memperoleh keuntungan perusahaan tidak bisa dengan hanya meningkatkan volume penjualan saja tetapi juga mengamati tingkah laku konsumen serta memenuhi keinginan konsumen melalui usahaperbaikan kualitas produk yang sesuai dengan harapan konsumen. Hal inilah yang perlu diperhatikan perusahaan agar dapat memasarkan produknya dan menciptakan keputusan pembelian konsumen.

Menurut Setiadi (2010: 332), “Keputusan pembelian adalah proses pengintegrasian yang mengkombinasikan sikap pengetahuan dua atau lebih perilaku alternatif, dan memilih salah satu diantaranya". Hal - hal yang menjadi keputusan pembelian yaitu pengenalan kebutuhan, pencarian informasi, evaluasi alternatif, keputusan pembelian, dan perilaku sesudah membeli.Dalam mengambil keputusan saat membeli kamar hotel, ada beberapa faktor yang menjadi pertimbangan oleh tamu yaitu product (produk), price (harga), promotion (promosi), place (tempat), (Lupiyoadi, 2013). Sejalan dengan hal tersebut, upaya yang dapat dilakukan dalam memasarkan suatu produk yakni dengan melakukan promosi.

Menurut Tjiptono (2008: 219) promosi adalah "Suatu bentuk komunikasi pemasaran yang berusaha menyebarkan informaasi, mempengaruhi, atau membujuk, dan mengingatkan pasar sasaran atas perusahaan dan produknya agar bersedia menerima, membeli dan loyal pada produk yang ditawarkan perusahaan bersangkutan". Suhardi (2018: 284), "Mengatakan mengkomunikasikan kepada masyarakat konsumen dapat dilakukan dengan 5 (lima) variabel, yaitu advertising (periklanan), personal selling (penjualan tatap muka),Sales Promotion (Promosi penjualan), public relation (hubungan masyarakat), dan direct marketing (pemasaran langsung)".

Salah satu hotel yang ada di Kota Padang yaitu Hotel Daima Padang. Hotel Daima Padang adalah hotel bintang tiga $(* * *)$ yang terletak di jalan Jenderal Sudirman No. 17 Padang, yang memiliki 7 department yaitu: Front Office Department, Food and Beverage Department, Sales and Marketing Department, Human Resource Department, Accounting Department, Engineering Department dan yang terakhir adalah 
Housekeeping Department dengan 54 orang karyawan dengan kapasitas 93 kamar, yaitu 48 kamar Superior, 38 kamar deluxe dan 7 kamar Family.

Meskipun hotel merupakan suatu usaha yang sangat menjanjikan, namun ada kalanya hotel mengalami penurunan tingkat hunian (occupancy) kamar, oleh sebab itu pihak manajemen hotel di tuntut untuk bisa memberikan ide - ide agar tamu lebih memilih membeli kamar di Hotel Daima Padang, hal ini harus diperhatikan agar tidak terjadi penuruanan tingkat hunian kamar yang sangat drastis jika dalam kondisi low season atau musim sepi. Berikut dapat dilihat pada Table 1.Tingkat Hunian Kamar di Hotel Daima Padang.

Table 1 Tingkat Hunian Kamar di Hotel Daima Padang Oktober 2018 - Maret 2019

\begin{tabular}{lllllc}
\hline No & Bulan & $\begin{array}{l}\text { Kamar } \\
\text { Terjual }\end{array}$ & $\begin{array}{l}\text { Target } \\
\text { Terjual }\end{array}$ & $\begin{array}{l}\text { Room } \\
\text { Occupancy }\end{array}$ & $\begin{array}{l}\text { Jumlah tamu individu } \\
\text { yang menginap }\end{array}$ \\
\hline 1 & Okt & 2.575 & 2.370 & $93.30 \%$ & 1.623 \\
\hline 2 & Nov & 2.588 & 2.370 & $93.77 \%$ & 1.531 \\
\hline 3 & Des & 2.526 & 2.370 & $91.52 \%$ & 1.567 \\
\hline 4 & Jan & 1.786 & 2.370 & $62.62 \%$ & 1.487 \\
\hline 5 & Feb & 1.776 & 2.370 & $68.94 \%$ & 1.380 \\
\hline 6 & Mar & 2.518 & 2.370 & $91.23 \%$ & 1.743 \\
\hline Jumlah rata-rata & 2.295 & 2.370 & $83.68 \%$ & 1.555 \\
\hline
\end{tabular}

Berdasarkan data Tabel 1 diatas tingkat hunian kamar dari bulan Oktober 2018 sampai dengan bulan Maret 2019, occupancy dari Hotel Daima Padang mencapai angka 50\% setiap bulannya. Meskipun occupancy Hotel Daima Padang mencapai angka 50\% tetapi hal tersebut belum sesuai dengan apa yang ditargetkan oleh pihak hotel. Didalam data tabel diatas, kamar yang ditargetkan akan terjual pada saat low season adalah sebanyak 2.370 kamar/bulan atau lebih kurang $85 \%$ dari ketersedian kamar/bulan, akan tetapi pada kenyataanya hanya tercapai (Room Occupaid) yaitu sebesar 2.295 kamar/bulan.

Kemudian dapat dilihat juga pada data Tabel 1 diatas menunjukan bahwa tingkat hunian kamar di Hotel Daima Padang tidak stabil, tentu hal ini wajar dalam sebuah usaha, tatapi peningkatan keputusan pembelian konsumen dapat dilakukan dengan memanfaatkan bauran promosi semaksimal mungkin sehingga akan meningkatkan tingkat hunian kamar di Hotel Daima Padang.

Hotel Daima Padang dalam usahanya meningkatkan occupancy melakukan bauran promosi sebagai salah satu cara untuk menarik keputusan pembelian oleh konsumen, seperti melakukan promosi melalui pembagian brosur, mempromosikan lewat alat komunikasi (telephone), mempromosikan lewat media masa/koran, melakukan sales call, presentasi ke perusahaan-perusahaan, pemberian diskon, serta mengadakan event untuk mengenalkan Hotel Daima Padang kepada konsumen.

Meskipun Hotel Daima Padang sudah memanfaatkan bauran promosi tetapi ada beberapa bauran promosi yang belum dilakukan seperti tidak adanya pemanfaatan media pendukung dalam kegiatan promosi seperti pengunaan spanduk dan baliho di pusat kota, kurang optimalnya kegiatan sales callstaff sales and marketing kepada konsumen group.

This is an open access article distributed under the Creative Commons 4.0 Attribution License, which permits unrestricted use, distribution, and reproduction in any medium, provided the original work is properly cited. (C2017 by author and Universitas Negeri Padang. 
Selain tidak efektifnya kegiatan bauran promosi tersebut, adanya masalah lain seperti kurangnya pengetahuan staffsales and marketing terhadap promo terbaru dari hotel hotel competitor.

Tujuan dari penelitian ini adalah untuk mendeskripsikan tentang bauran promosi di Hotel Daima Padang, mendeskripsikan keputusan pembelian kamar di Hotel Daima Padang dan menganalisis pengaruh bauran promosi terhadap keputusan pembelian kamar di Hotel Daima Padang.

\section{Metode}

Jenis penelitian ini adalah kuantitatif dengan metode asosiatif kausal. Populasi dalam penelitian ini adalah tamu yang menginap dengan rata-rata perbulan yaitu 1.555 orang. Teknik pengambilan sampel adalah non probability sampling, dengan menggunakan metode purpossive sampling. Jumlah sampel dalam penelitian ini berjumlah 94 orang.

Pengumpulan data menggunakan angket berdasarkan Skala Likert yang telah teruji validitas dan reliabilitasnya. Teknik analisis data penelitian ini menggunakan rumus penelitian ideal (Mi), standart deviation (Sdi), dan diklasifikasikan menjadi 5 kategori menurut Arikunto (2010) yaitu:

$$
\begin{array}{ll}
\text { Kategori sangat baik } & : \geq(\mathrm{Mi}+1,5 \mathrm{Sdi})-\mathrm{Keatas} \\
\text { Kategori baik } & :(\mathrm{Mi}+0,5 \mathrm{Sdi})-<(\mathrm{Mi}+1,5 \mathrm{Sdi}) \\
\text { Kategori cukup } & :(\mathrm{Mi}-0,5 \mathrm{Sdi})-<(\mathrm{Mi}+0,5 \mathrm{Sdi}) \\
\text { Kategori buruk } & :(\mathrm{Mi}-1,5 \mathrm{Sdi})-<(\mathrm{Mi}-0,5 \mathrm{Sdi}) \\
\text { Kategori sangat buruk } & :<(\mathrm{Mi}-1,5 \mathrm{Sdi})-\text { Kebawah }
\end{array}
$$

Untuk menentukan skor rata-rata ideal digunakan patokan kurva normal sebagai berikut:

$\mathrm{Mi}=1 / 2($ skor ideal maksimum + skor ideal minimum $)$

Sdi $=1 / 6$ (skor ideal maksimum - skor ideal minimum)

Uji persyaratananalisis menggunakan uji normalitas dengan asymp. Sig. untuk variabel bauran promosi adalah 0,165 dan variabel keputusan pembelian kamar adalah 0,152 kemudian untuk uji homogenitas dengan nilai Sig. sebesar 0,104 berarti > 0,05. Hasil penelitian dengan menggunakan uji t menunjukan bahwa kelima indikator bauran promosi (periklanan, penjulan tatap muka, promosi penjualan, hubungan masyarakat dan pemasaran langsung) mempengaruhi keputusan pembelian sebagai variabel dependen secara signifikan dengan nilai $\mathrm{R}$ square sebesar 0,239

\section{Teknik Analisis Data}

\section{Uji persyaratan analisis}

\section{Uji Normalitas}

Uji normalitas dilakukan dengan uji kolmogrov smirnov dengan menggunakan alat bantu komputer program SPSS versi 18.00 dengan ketentuan sebagai berikut: (1) Nilai Sig./signifikansi atau probabilitas $\leq 0,05$, distribusi adalah tidak normal (asimetris).(2) Nilai Sig./signifikansi atau probabilitas > 0,05, distribusi adalah normal (simetris).

\section{Uji Homogenitas}

Uji Homogenitas dilakukan untuk melihat apakah sampel yang berasal dari populasi memiliki krakteristik yang sama atau tidak. Untuk pengujian ini digunakanuji Test of Homogenity of Variances. Kriteria pengujiannya adalah: 
Jika nilai signifikansi (Sig) atau nilai probabilitas $(\mathrm{p})>0,05$ maka dapat dikatakan data tersebut berasal dari populasi yang mempunyai banyak varian yang sama atau data besifat homogen.

Jika nilai signifikansi (Sig) atau nilai probabilitas $(\mathrm{p}) \leq 0,05$ maka dapat dikatakan data tersebut berasal dari populasi yang mempunyai varian yang tidak sama atau data besifat tidak homogen.

\section{Uji Linearitas}

Uji Linearitas bertujuan untuk mengetahui apakah dua variabel mempunyai hubungan yang linear atau tidak secara signifikan.Dua variabel dikatakan mempunyai hubungan linear bila nilai Deviation from Linearity > 0.05.Uji ini biasanya digunakan sebagai persyaratan dalam analisis korelasi atau regresi linear.

\section{HASIL DAN PEMBAHASAN}

\section{Hasil Penelitian}

\section{Bauran Promosi}

Berdasarkan data penelitian diketahui bahwa distribusi skor jawaban untuk variabel bauran promosi menyebar dari skor terendah (minimum) 48 dan skor tertinggi (maximum) 64, skor rata-rata (mean) sebesar 53,11, skor tengah (median) sebesar 53,00, skor yang sering muncul (mode) 54, simpangan baku (standart deviation) 2,953, range 16 dan varian 8,720. Data klasifikasi skor variabel bauran promosi dapat dilihat pada Tabel 2 berikut:

Table 2 Klasifikasi Skor Jawaban Responden Tentang VariabelBauran Promosi

\begin{tabular}{llcc}
\hline \multicolumn{1}{c}{ Kategori } & Skor & Frekuensi & Persentase \\
\hline Sangat Baik & $\geq 64$ & 0 & 0 \\
\hline Baik & $53-64$ & 54 & 57 \\
\hline Cukup & $43-53$ & 40 & 43 \\
\hline Buruk & $32-43$ & 0 & 0 \\
\hline $\begin{array}{l}\text { Sangat } \\
\text { Buruk }\end{array}$ & $<32$ & 0 & 0 \\
\hline Total & & 94 & 100 \\
\hline
\end{tabular}

Berdasarkan pengkategorian skor dan nilai rata-rata (mean) terlihat bahwa penilian tamu tentang variabel bauran promosi sebesar 53,11 berada pada rentang 53 -< 64 dengan kategori baik. Selanjutnya hasil bauran promosi yang ditinjau dari indikatornya sebagai berikut:

\section{Keputusan Pembelian}

Berdasarkan data penelitian diketahui bahwa distribusi skor jawaban untuk variabel keputusan pembelian menyebar dari skor terendah (minimum) 42 dan skor tertinggi (maximum) 59, skor rata-rata (mean) sebesar 53,18, skor tengah (median) sebesar 54,00, skor yang sering muncul (mode) 52, simpangan baku (standart deviation) 3,090 , range 17 dan varian 9,548. Data klasifikasi skor variabel keputusan pembelian dapat dilihat pada Tabel 3 berikut: 
Table 3 Klasifikasi Skor Jawaban Responden Tentang Variabel Keputusan Pembelian

\begin{tabular}{llll}
\hline \multicolumn{1}{c}{ Kategori } & Skor & Frekuensi & Persentase \\
\hline Sangat Baik & $\geq 56$ & 25 & 27 \\
\hline Baik & $47-<56$ & 67 & 71 \\
\hline Cukup & $37-<47$ & 2 & 2 \\
\hline Buruk & $28-<37$ & 0 & 0 \\
\hline Sangat Buruk & $<28$ & 0 & 0 \\
\hline \multicolumn{1}{c}{ Total } & & 94 & 100 \\
\hline
\end{tabular}

Berdasarkan pengkategorian skor dan nilai rata-rata (mean) terlihat bahwa penilian tamu tentang variabel keputusan pembelian sebesar 53,18 berada pada rentang 47 - < 56 dengan kategori baik.

\section{Uji Persyaratan Analisis}

\section{Uji Normalitas}

Uji normalitas bertujuan untuk mengetahui data berdistribusi secara normal atau tidak.Pengujian normalitas bauran promosi dan keputusan pembelian dilakukan dengan mengunakan uji kolmogrov-smirrnov. Taraf signifikansi yang digunakan sebagai dasar menolak atau menerima keputusan normal atau tidaknya suatu distribusi data adalah 0,05. Hasil uji normalitas dapat dilihat pada tabel berikut ini:

Table 4 Uji Normalitas dengan One-Sample Kolmogorov-Smirnov Test

\begin{tabular}{clcc}
\hline \multirow{2}{*}{$\mathrm{N}$} & & Bauran Promosi & Keputusan Pembelian \\
\hline Normal Parameters $^{\mathrm{a}}$ & & 94 & 94 \\
\hline \multirow{2}{*}{ Most Extreme Differences } & Mean & 53.11 & 53.18 \\
\cline { 2 - 4 } & Std. Deviation & 2.953 & 3.090 \\
\cline { 2 - 4 } & Absolute & .115 & .117 \\
\cline { 2 - 4 } & Positive & .115 & .076 \\
\hline \multicolumn{2}{c}{ Kolmogative } & -.076 & -.117 \\
\hline Asymp. Sig. (2-tailed) & & 1.116 & 1.136 \\
\hline \multicolumn{2}{c}{ a.Test distribution is Normal. } & .165 & .152 \\
\hline
\end{tabular}

Tabel 4 diatas menunjukan bahwa nilai asymp. Sig untuk variable bauran promosi adalah 0,165 dan untuk keputusan pembelian adalah 0,152 dengan nilai > dari 0,05, maka dapat dikatakan bahwa kedua data terdistribusi normal.

\section{Uji Homogenitas}

Uji homogenitas bertujuan untuk melihat apakah kedua sampel homogen yaitu mempunyai varians yang sama atau tidak antara variabel bauran promosi $(\mathrm{X})$ dengan variabel keputusan pembelian (Y), untuk pengujian ini digunakan uji Test of Homogenity of Variances menggunakan bantuan program SPSS 16.00. Hasil analisis uji homogenitas dapat dilihat pada tabel berikut:

Jika nilai signifikan (Sig) atau nilai probabilitas $(p) \geq 0,05$ maka dapat dikatakan data tersebut berasal dari populasi yang mempunyai varian yang sama atau data bersifat homogen. 
Jika nilai signifikan (Sig) atau niali probabilitas (p) $<0,05$ maka dapat dikatakan data tersebut berasal dari populasi yang mempunyai varian yang tidak sama atau data bersifat tidak homogen. Hasil analisis uji homogenitas dapat dilihat pada tabel berikut:

Table 5 Uji Homogenitas

\begin{tabular}{llll}
\hline \multicolumn{4}{c}{ Test of Homogeneity of Variances } \\
\hline Keputusan Pembelian & & & \\
\hline Levene Statistic & df1 & df2 & Sig. \\
\hline 1.635 & 11 & 81 & .104 \\
\hline
\end{tabular}

Berdasarkan hasil analisis uji homogenitas pada Tabel 5 diatas diperoleh nilai Sig adalah 0,104 dengan taraf signifikan > 0,05, ini artinya nilai signifikansi data lebih besar dari taraf signifikansi. Sehingga dapat diambil kesimpulan bahwa data berasal dari populasi yang mempunyai varians yang sama atau data bersifat homogen.

\section{Uji Linearitas}

Uji linearitas betujuan untuk mengetahui apakah dua variabel mempunyai hubungan yang linear atau tidak secara signifikan.Uji ini biasanya digunakan sebagai persyaratan dalam analisis korelasi atau regresi linear. Jika Deviation From Linearity yang ditunjukan oleh Sig. > 0,05, berarti hubungan antara predictor dengan dependent variabel adalah linear. Hasil uji linearitas dapat dilihat pada Tabel berikut:

Table 6 Uji Linearitas (ANOVA)

\begin{tabular}{|c|c|c|c|c|c|c|c|}
\hline & & & $\begin{array}{l}\text { Sum } \\
\text { Squares }\end{array}$ & Df & $\begin{array}{l}\text { Mean } \\
\text { Square }\end{array}$ & $\mathrm{F}$ & Sig. \\
\hline \multirow{5}{*}{$\begin{array}{l}\text { Keputusan } \\
\text { Pembelian } \\
\text { Bauran } \\
\text { Promosi }\end{array}$} & \multirow{3}{*}{$\begin{aligned} & \text { Between } \\
* & \text { Groups }\end{aligned}$} & (Combined) & 316.886 & 12 & 26.407 & 3.746 & .000 \\
\hline & & Linearity & 212.574 & 1 & 212.574 & 30.153 & .000 \\
\hline & & $\begin{array}{l}\text { Deviation } \\
\text { from } \\
\text { Linearity }\end{array}$ & 104.312 & 11 & 9.483 & 1.345 & .216 \\
\hline & \multicolumn{2}{|c|}{ Within Groups } & 571.040 & 81 & 7.050 & & \\
\hline & \multicolumn{2}{|c|}{ Total } & 887.926 & 93 & & & \\
\hline
\end{tabular}

Berdasarkan hasil uji linearitas pada Tabel 6 diatas, diperoleh nilai Sig adalah 0,216 dengan taraf signifikansi $>0,05$, yang artinya terdapat hubungan linear secara signifikan antara variabel bauran promosi (X) dan keputusan pembelian (Y).

\section{Pembahasan}

\section{Bauran Promosi}

Berdasarkan hasil deskripsi penelitian bauran promosi di Hotel Daima Padang. Dilihat dari pengkategorian skor dan rata-rata (mean) maka hasil distribusi frekuensi 94 responden bauran promosi sebesar 54 orang $(57 \%)$ responden berada pada rentang skor 53 - 64 menunjukan kategori baik, dan 40 orang $(43 \%)$ responden berada pada rentang skor 43 - 53 menunjukan kategori cukup. Dengan demikian disimpulkan bahwa bauran promosi di Hotel Daima Padang secara keseluruhan dikategorikan baik.

Menurut Tjiptono (2008: 219) menjelaskan bahwa "Promosi adalah suatu bentuk komunikasi pemasaran yang berusaha menyebarkan informaasi, mempengaruhi, atau membujuk, dan mengingatkan pasar sasaran atas perusahaan dan produknya agar

his is an open access article distributed under the Creative Commons 4.0 Attribution License, which permits unrestricted use, distribution, and reproduction in any medium, provided the original work is properly cited. (C2017 by author and Universitas Negeri Padang. 
bersedia menerima, membeli dan loyal pada produk yang ditawarkan perusahaan bersangkutan".

Pengaruh bauran promosi yang tepat dengan intensitas yang tinggi akan menjadikan konsumen mengenal dan ada rasa penasaran terhadapa produk dan jasa yang di promosikan. Bauran promosi sendiri merupakan sarana untuk membangun kepercayaan dan penilaian konsumen terhadap produk dan jasa, dengan membina hubungan erat antara pihak perusahaan dengan kosumen melalui pendekatan strategi bauran promosi yang tepat akan mempengaruhi konsumen memberikan keputusan pembelian. (Abdullah dan Tantri, 2016).

\section{Keputusan Pembelian}

Berdasarkan hasil deskripsi penelitian keputusan pembelian di Hotel Daima Padang. Dilihat dari pengkategorian skor dan rata-rata maka hasil distribusi frekuensi 94 responden keputusan pembelian sebesar 25 orang (27\%) responden berada pada rentang skor 56 menunjukan kategori sangat baik, 67 orang (71\%) responden berada pada rentang skor 47 - 56 menunjukan kategori baik, kemudian 2 orang (2\%) responden berada pada rentang skor 37 - 47 menunjukan kategori cukup. Dengan demikian disimpulkan bahwa keputusan pembelian di Hotel Daima Padang secara keseluruhan dikategorikan baik.

Menurut Tjiptono (2008: 21) keputusan pembelian adalah, "Sebuah proses dimana konsumen mengenal masalahnya, mencari informasi mengenai produk atau merek tertentu dan mengevaluasi seberaba baik masing - masing alternatif tersebut dapat memecahkan masalahnya, yang kemudian mengarah kepada keputusan pembelian". Saat ini pemikiran tentang keputusan pembelian konsumen tidak lagi sebagai tahap akhir dari sebuah proses konsumsi, namun merupakan tahap awal dari proses konsumsi. Berdasarkan teori tersebut menunjukan bahwa keputusan pembelian adalah suatu keputusan seseorang dimana dia memilih salah satu dari beberapa alternatif pilihan yang ada dan proses integrasi yang mengkombinasikan sikap pengetahuan untuk mengevaluasi dua atau lebih perilaku alternatif dan memilih salah satu diantaranya.

\section{Pengaruh Bauran Promosi Terhadap Keputusan Pembelian Kamar di Hotel Daima Padang}

Berdasarakan hasil uji hipotesis yang digunakan untuk mengetahui derajat pengaruh antara bauran promosi terhadap keputusan pembelian di Hotel Daima Padang. Analisis dilakukan dengan bantuan SPSS Versi 16.00 diperoleh hasil Hasil sebagai berikut: (1) Nilai konstanta sebesar 25.991 menunjukan bahwa bauran pomosi berpengaruh terhadap keputusan pembelian kamar. (2) Uji regresi linear sederhana yaitu $\mathrm{t}$ hitung $5.381>\mathrm{t}$ tabel dengan Sig. 0,000, maka variabel bauran promosi (X) mempunyai hubungan secara signifikan terhadap keputusan pembelian (Y). Selanjutnya di peroleh koefisien regresi sebesar 0,512 dengan nilai t hitung 5.381 pada Sig. $0,000<$ 0,05 . Artinya setiap peningkatan sebesar 1 satuan bauran promosi akan meningkatkan 0,512 satuan keputusan pembelian.

Kemudian diperoleh nilai $\mathrm{R}$ square 0,239. Artinya pengaruh variabel bauran promosi (X) terhadap variabel keputusan pembelian (Y) adalah sebesar 23,9\%. Sedangkan 76,1\% dipengaruhi faktor lain seperti faktor produk, harga, dan lokasi . Maka hipotesis yang diterima dalam penelitian ini adalah Ha dan Ho ditolak.

Hasil penelitian menunjukan bahwa variabel bauran promosi memberikan pengaruh yang signifikan terhadap keputusan pembelian kamar di Hotel Daima Padang dengan persentase sebesar 23,9\%. Artinya konsumen menjadikan bauran promosi sebagai pertimbangan dalam memberikan keputusan pembelian kamar karena konsumen menganggap manfaat yang diterima sesuai dengan kebutuhan yang mereka inginkan. 
Kegiatan perusahaan dalam mempromosikan produk yang dipasarkan termasuk salah satu faktor pendukung dan hal tersebut akan menjadi kekuatan (strength) bagi perusahaan dalam menghadapi persaingan. Sehingga apabila perusahaan melakukan bauran promosi yang positif atau baik, maka konsumen akan semakin yakin pula untuk melakukan keputusan pembeliannya. bahwa:

Temuan ini juga sesuai dengan hasil penelitian Tiffany (2015) yang berpendapat

"Hasil penelitian menujukan bahwa terdapat hubungan yang positif dan signifikan antara promosi yang dengan keputusan pembelian kamar tamu di Hotel Bumiminang Padang.Hal ini berarti semkain baik promosi yang dilakukan oleh Hotel Bumiminang Padang, maka keputusan pembelian kamar oleh konsumen semakin tinggi”.

Sejalan dengan penelitian Afni (2018) yang berpendapat bahwa:

"Wisatawan menjadikan promosi sebagai pertimbangan dalam menimbulkan minat beli suatu produk karena wisatawan menganggap manfaat yang diterima sesuai dengan kebutuhan yang mereka inginkan”.

\section{Simpulan}

Berdasarkan hasil penelitian yang telah dilakukan dapat diambil kesimpulan sebagai berikut: (1) Bauran Promosi di Hotel Daima Padang secara keseluruhan berada pada kategori baik dengan persentase 57\%. (2) Keputusan Pembelian kamar di Hotel Daima Padang secara keseluruhan berada pada kategori baik dengan persentase $71 \%$. Terdapat pengaruh yang signifikan antara bauran promosi terhadap keputusan pembelian kamar di Hotel Daima Padang sebesar 23,9\% dan 76,1\% dipengaruhi oleh variable lain yang tidak dibahasa dalam penelitian ini.

\section{Saran}

Dari hasil penelitian yang didapat serta analisa yang telah penulis lakukan pada bab-bab sebelumnya, maka yang dapat menjadi arahan bagi Hotel Daima Padang adalah sebagai berikut:

Perlu dilakukan penelitian lanjutan untuk mengetahui faktor lain yang mempengaruhi keputusan pembelian kamar di Hotel Daima Padang sperti kualitas produk, harga dan lokasi. Bauran promosi yang dilakukan Hotel Daima Padang saat ini harus diperhatikan dan ditingkatkan lagi. Hotel Daima Padang harus lebih meningkatkan promosi periklanannya seperti iklan media luar ruangan dan kegiatan penjualan tatap muka. Sebaiknya pengunaan spanduk dan baliho di pusat kota atau tempat-tempat umum harus diterapkan sehingga penyebaran informasi lebih luas.

\section{Daftar Pustaka}

Abdullah dan Tantri, 2016.Manajemen Pemasaran. Jakarta: PT. RajaGrafindo Persada.

Afni, Adillah, Noer. 2018. Pengaruh Promosi Terhadap Minat Beli Wisatawan Menginap di Grand Royal Denai Hotel Bukittinggi (Skripsi). Fakultas Pariwisata dan Perhotelan, Padang: Universitas Negeri Padang.

Arikunto, Suharsimi. 2010. Manajemen Penelitian. Jakarta: PT. Rineka Cipta.

Budi, Agung Permana. 2013. Manajemen Marketing Perhotelan. Yogyakarta: Andi.

This is an open access article distributed under the Creative Commons 4.0 Attribution License, which permits unrestricted use, distribution, and reproduction in any medium, provided the original work is properly cited. (C2017 by author and Universitas Negeri Padang. 
Lupiyoadi, Rambat. 2013. Manajemen Pemasaran Jasa, Edisi 3. Jakarta: Salemba Empat.

Setiadi, Nugroho J. 2010. Perilaku Konsumen. Jakarta: PT. Kencana Prenada Media Group.

Suhardi. 2018. Pengantar Manajemen Dan Aplikasinya. Yogyakarta: Gava Media

Tiffany, Intan, Yuliana, Kasmita. 2015. Hubungan Promosi Dengan Keputusan Pembelian Kamar Tamu di Hotel Bumiminang Padang. Vol. 11,

No.3.http://ejournal.unp.ac.id/index.php/jhet/article/view/5469 (diakses tanggal 6 Juli 2019).

Tjiptono, Fandy. 2008. Strategi Pemasaran, Edisi 3. Yogyakarta: Andi. 